\title{
Evaluation of the Effect of Deposition $\mathrm{pH}$ on the Physico- chemical Properties of Electrochemically Deposited Cadmium Telluride for Photovoltaic Device Applications
}

\author{
Ayotunde Adigun Ojo, Kolade Olanipekun, Benjamin Oluwadare, and Taiwo O. Oni
}

\begin{abstract}
Two-electrode (2E) configuration was successfully utilised in the electrochemical deposition of cadmium telluride (CdTe) on fluorine-doped tin oxide (FTO) substrate with the main emphasis on the electrolytic bath $\mathrm{pH}$. The electrochemical deposition $\mathrm{pH}$ explored is within the range of (1.00 to 6.00) \pm 0.02 for the aqueous electrolyte comprising of tellurium oxide (TeO2) and cadmium nitrate (Cd(NO3)2) which are the respective precursors of $\mathrm{Te}$ and $\mathrm{Cd}$. The optical, structural, morphological, compositional, and electrical properties of the electroplated CdTe thin-films were respectively explored using UV-Vis spectrophotometry, X-ray diffraction (XRD), scanning electron microscopy (SEM), energy dispersive $\mathrm{X}$-ray (EDX), and photoelectrochemical (PEC) cell measurements. The optical characterisation show that the CdTe samples exhibit dissimilar absorbance depending on the growth $\mathrm{pH}$ for both the as-deposited layers and post-growth treated CdTe layers. $A$ decrease in the absorption edge slope and dip in the bandgap was observed away from $\mathrm{pH} 2$. The bandgap of the post-growth treated CdTe layers showed enhancement as it leans towards $1.45 \mathrm{eV}$, with the trend retention of absorption edge slope, similar to the asdeposited CdTe layers. The electrodeposited CdTe thin-films show a dominant orientation along the cubic (111) CdTe plane, while both the the calculated crystallite size and the XRD peak intensity $\mathrm{Pi}$ decreases with the electroplating $\mathrm{pH}$ outside the (2.00 to 3.00) \pm 0.02 range. The EDX analyses depicts an alteration in the ratio of $\mathrm{Cd}$ to $\mathrm{Te}$ atomic percentage relative to the $\mathrm{pH}$ of the electrolyte. Comparatively high Te atomic ratio was observed at lower $\mathrm{pH}$ values and vice versa with increase alkalinity of the electrolyte. The obtained morphology depicts that the underlying FTO layers are well covered with a gradual reduction in the grain size of the CdTe observable away from pH value (2.00 and 3.00). The photoelectrochemical cell study depicts that the conduction type of the CdTe layers can also be attributed to the CdTe-electrolytic bath $\mathrm{pH}$ value.
\end{abstract}

Index Terms - CdTe, Electroplating, pH, Optimisation, Photovoltaics, Two electrode.

Submitted on March 14 01, 2021.

Published on September 06, 2021.

Ayotunde A. Ojo, Mech. Engineering Department, Ekiti State University, Ado-Ekiti, Nigeria.

(e-mail: ayotunde.ojo ${ }^{@}$ eksu.edu.ng)

Kolade A. Olanipekun, Mech. Engineering Department, Ekiti State University, Ado-Ekiti, Nigeria.

(e-mail: ayotunde.ojo@eksu.edu.ng)

Benjamin S. Oluwadare, Mech. Engineering Department, Ekiti State University, Ado-Ekiti, Nigeria.

(e-mail: ayotunde.ojo@eksu.edu.ng)

Taiwo O. Oni, Mech. Engineering Department, Ekiti State University, Ado-Ekiti, Nigeria.

(e-mail: tooni1610@yahoo.com)

\section{INTRODUCTION}

II-VI semiconductor material such as Cadmium telluride $(\mathrm{CdTe})$ is well-recognised in the photovoltaic (PV) community due to its optimal and direct bandgap, in conjunction with its high coefficient absorption [1]. CdTe has been identified as one of the possible candidates for achieving highly efficient photovoltaic system in the conventional $\mathrm{CdS} / \mathrm{CdTe}$ solar cell in the simplest configuration of either an n-p or n-n-Schottky barrier [2]. The growth of CdTe as a layer or incorporated in a CdTebased solar cell in the conventional $\mathrm{CdS} / \mathrm{CdTe}$ has been performed using electroplating and reported in the literature [3]-[5]. But the process optimisation of electroplating is scarce in the literature. It is a known fact that presiding electroplating parameters have an impact on the physicochemical properties of the grown layers [6]-[8]. For $\mathrm{CdTe}$, literature on the effect of electrolyte $\mathrm{pH}$ value on the characteristic properties of electroplated CdTe is yet to be documented in the literature. Hence, the research work focuses on bridging the knowledge gap by exploring the effect of deposition electrolyte $\mathrm{pH}$ on the characteristic properties of electrodeposited CdTe thin films.

\section{EXPERIMENTAL PROCEDURE}

CdTe layers were deposited electrochemically from an aqueous electrolytic bath comprising of $1.5 \mathrm{M}$ cadmium nitrate $\left(\mathrm{Cd}\left(\mathrm{NO}_{3}\right)_{2}\right)$ and $0.002 \mathrm{M}$ tellurium oxide $\left(\mathrm{TeO}_{2}\right)$ in $400 \mathrm{ml}$ of de-ionised (DI) water. The $\mathrm{Cd}\left(\mathrm{NO}_{3}\right)_{2}$ and $\mathrm{TeO}_{2}$ serves as the respective precursors of cadmium $(\mathrm{Cd})$ and tellurium (Te), while the ensuing solution will be denoted to as CdTe-electrolyte from now. For these sets of experiment, five replicas of CdTe-bath were prepared and the conditions such as growth temperature and stirring rate were maintained at $85{ }^{\circ} \mathrm{C}$ and $\sim 300 \mathrm{rpm}$, respectively. The acidity of the CdTe-electrolytes was adjusted to $\mathrm{pH} 1.00 \pm 0.02$, $2.00 \pm 0.02,3.00 \pm 0.02,4.00 \pm 0.02$ and $6.00 \pm 0.02$ by adding either dilute Nitric acid $\left(\mathrm{HNO}_{3}\right)$ or dilute ammonium hydroxide $\left(\mathrm{NH}_{4} \mathrm{OH}\right)$ solution to reduce or increase the $\mathrm{pH}$ of the CdTe-electrolyte correspondingly. For all the CdTebaths, the $400 \mathrm{ml}$ solution were occupied in a $500 \mathrm{ml}$ polypropylene beaker, which is concentrically inserted in a $1000 \mathrm{ml}$ glass beaker with a low level of DI water to achieve a relatively constant heating of the CdTe-electrolyte.

The conducting substrates utilised for these experiments is a $7 \Omega / \mathrm{sq}$ sheet resistant fluorine doped tin oxide (FTO) substrate coated on highly transparent glass. The glass/FTO substrate which serves as the cathode in the 2-electrode 
electrodeposition configuration were cut into a sheet of $2.5 \times 2 \mathrm{~cm}^{2}$ area while high purity graphite rod serves as the anode. Prior to electroplating, the glass/FTO substrates were washed ultrasonically in a bath containing soap solution, the substrates were rinsed in running DI water before being degreased using acetone and methanol. The substrate cleansing process was concluded by rinsing the glass/FTO substrate in running DI water and transferred into the CdTeelectrolytic bath for the required connections to be made (see Ref [2]). It should be noted that about $2 \times 2 \mathrm{~cm}^{2}$ area of the substrate was in contact with the electrolyte due to the $0.5 \times 2 \mathrm{~cm}^{2}$ area covered in fastening the substrate with the carbon electrode plate using polytetrafluoroethylene (PTFE) tape. The conducting substrate and the chemicals utilised were sourced from Sigma Aldrich Ltd, UK.

The power source utilised in this two-electrode ED configuration is an ACM GillAC potentiostat. Following the deposition of CdTe, the glass/FTO/CdTe layers were bathed in DI water, dried in a nitrogen gas-rich stream of air, and cut into equal halves. One half is left as deposited (AD) while the other half undergo post-growth cadmium chloride $(\mathrm{CdCl} 2)$ treatment $(\mathrm{CCT})$. The $\mathrm{CCT}$ treatment process utilised for this set of experiment is well discussed in Ref [2]. CCT has been documented in the literature to have positive impact on both the electronic and material properties of CdTe.

Both the AD and the CCT-CdTe samples were examined for their optical properties using Cary50 Scan UV-visible spectrophotometer, structural properties using Philips PW 3710 X'pert X-ray diffraction (XRD) machine. Both the morphological and compositional data were obtained using FEI Nova200 NanoSEM, and the electrical properties using photoelectrochemical (PEC) cell measurements with respect to the deposition $\mathrm{pH}$.

\section{RESUlTS AND DISCUSSION}

It is well established in the literature that the deposition potential of electroplated semiconductor such as CdTe, $\mathrm{ZnS}$, $\mathrm{ZnTe}$ etcetera can be a viable factor in determining the characteristic properties of the electroplated layers [9]-[12]. Therefore, based on the previous research work by the principal author's group, an optimal deposition potential of $1400 \mathrm{mV}$ was utilised for the growth of all the glass/FTO/CdTe layers. The layers were grown for $\sim 2 \mathrm{hrs}$ each with a thickness of $0.8 \mathrm{\eta m}$, estimated using Faraday's law of electrolysis (see (1)).

$$
T=\frac{J t M}{n F \rho}
$$

where $\mathrm{T}$ is the thickness $(\mathrm{cm}), \mathrm{t}$ is the deposition time $(\mathrm{s}), \mathrm{M}$ is the molecular mass $\left(\mathrm{gmol}^{-1}\right), \mathrm{J}$ is current density $\left(\mathrm{Acm}^{-2}\right)$, $\rho$ is the density $\left(\mathrm{gcm}^{-3}\right), \mathrm{A}$ is the surface area of the substrate in contact with the electrolyte $\left(\mathrm{cm}^{2}\right), \mathrm{F}$ is the Faraday's constant $\left(96485 \mathrm{Cmol}^{-1}\right)$, and the number of electrons transferred in the chemical reaction for the formation of 1 mole of substance in $\mathrm{gcm}^{-3}$ is denoted as $\mathrm{n}$. In addition, the reported results were repeated severally to ascertain the reproducibility of the trend of results

\section{A. Optical Bandgap Determination}

The optical characteristic properties of the deposited CdTe layers under investigation was ascertained by acquiring the optical absorption data between the wavelength range of (200 and $800 \mathrm{~nm})$ at room temperature. Prior to the measurement, a baseline of plain glass/FTO (a replica of the substrate on which CdTe was electroplated) was set as the baseline to mitigate the imprint of both the FTO and glass on the results obtained. Optically, the estimation of the bandgap was determined graphically from Tauc's plot of $(\alpha h v)^{2}$ against $(h v)$ [13] (see (2)).

$$
\alpha=\frac{k\left(h v-E_{g}\right)^{m}}{h v}
$$

where $h$ symbolises the Plank's constant, $\alpha$ symbolises the absorption coefficient, $v$ symbolises the incident photon frequency, the constant of proportionality $\mathrm{k}$ dependents on the refractive index of the sample under investigation, and $\mathrm{m}$ equals 0.5 for a direct bandgap semiconductor.

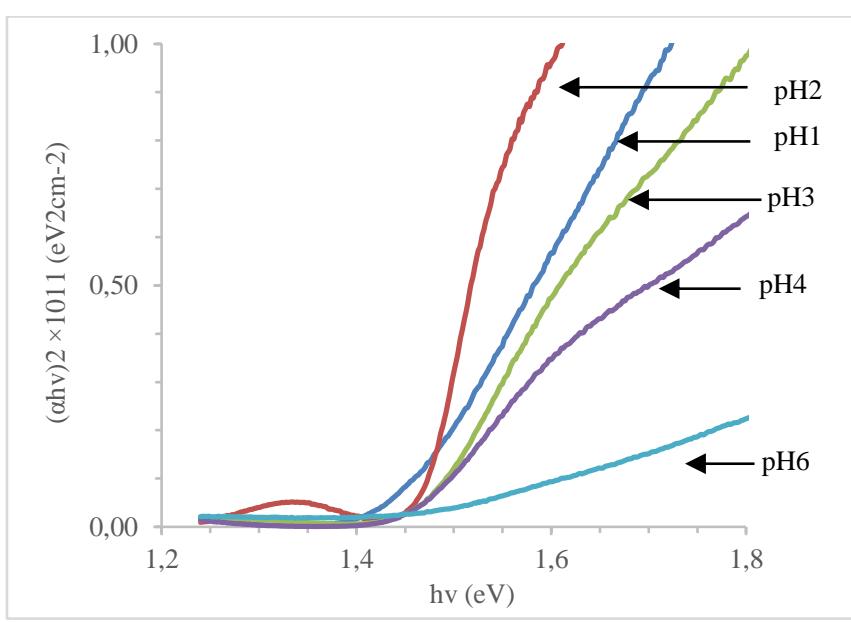

(a)

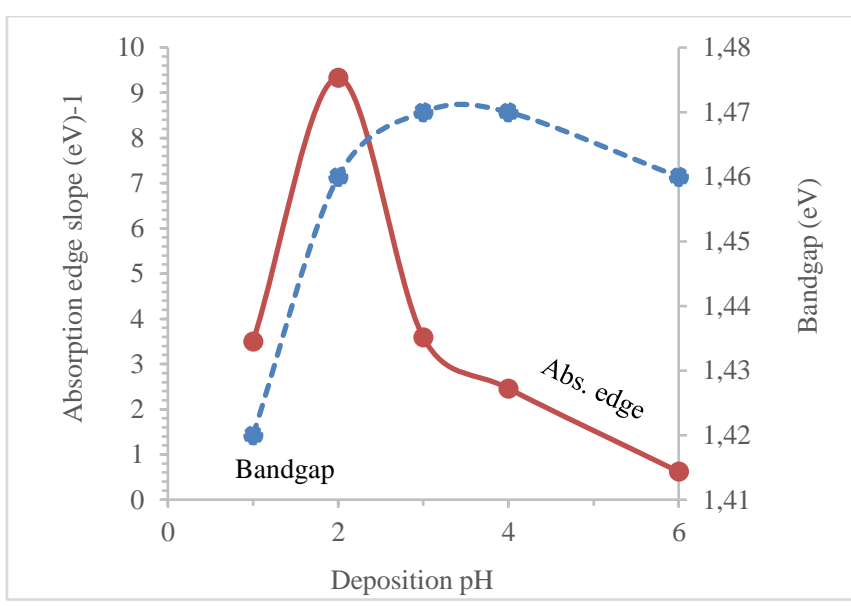

(b)

Fig. 1. (a) Tauc's plot of the electroplated CdTe layers from electrolytes with respect to deposition $\mathrm{pH}$ and (b) The plot of the absorption edge slope and bandgap of the CCT CdTe layers against deposition $\mathrm{pH}$.

The estimate of the energy bandgap is the magnitude of 
photon energy $h v$ obtained as a result of the straight line portion of the graph extrapolated to $(\alpha h v)^{2}=0$. Fig. 1 (a) shows the $A^{2}$ versus $h v$ graph of optical bandgap of CdTe grown from CdTe-baths at different deposition $\mathrm{pH}$ and Fig. 1 (b) shows the CCT CdTe layers absorption edge slope against the $\mathrm{pH}$ of the deposition electrolyte. With respect to Fig. 1, it was observed that the bandgaps across all the deposition $\mathrm{pH}$ explored were within the $1.44 \pm 0.03 \mathrm{eV}$ range. This observation is interesting due to the closeness of the obtained value to the known CdTe bulk bandgap of $1.45 \mathrm{eV}$ with the CdTe thin film from the $\mathrm{pH} 2$ bath being the closest at $1.46 \mathrm{eV}$. However, the band absorption edge which depicts the impurity energy level and defect [14], [15] differs. Superior CdTe layer are known to have the sharpest absorption edge which signify lesser impurity energy level and defects as observed from the CdTe layer deposited from the $\mathrm{pH} 2$ electrolyte as compared to other layers grown outside this $\mathrm{pH}$ range. It should be noted that asides the inherent impurities in the precursors utilised, richness or deficiency of either $\mathrm{Te}$ and $\mathrm{Cd}$ and other inhibited ions in the electrolyte may constitute or broaden defect distribution within the bandgap [16], [17].

\section{B. X-ray Diffraction (XRD) Measurements}

The Philips PW 3710 X'pert diffractometer XRD system utilised for this set of experiments was incorporated with a with a diffracted beam monochromator and $\mathrm{Cu} \mathrm{K} \alpha$ radiation with a $1.54 \AA$ wavelength. Both the X-ray source tension and current were fixed at $40 \mathrm{kV}$ and $40 \mathrm{~mA}$ respectively. The $2 \theta$ angle spanning between ( 20 to $70^{\circ}$ ) was explored and the obtained data were analysed using X'pert HighScore Plus software. The crystallite size D was estimated using Scherrer's equation (see (3)). The $\beta$ symbolises the fullwidth-at-half-maximum (FWHM) of the diffraction intensity in radians, $\theta$ symbolises the Bragg angle, and $\lambda$ symbolises the X-rays wavelength $(1.54 \AA)$. The incorporated 0.94 is the shape constant for the spherical geometry.

$$
D=\frac{0.94 \lambda}{\beta \cos \theta}
$$

The internal micro-strain, $\varepsilon$, describes the crystallites distortion due to compressive or tensile stress is evaluated using (4) as reported in the literature [18].

$$
\varepsilon=\frac{\beta}{4 \tan \theta}
$$

The dislocation density, $\delta$, describes the length of dislocation lines per unit volume of crystal in the thin-film is calculated using (5)) as documented in [19].

$$
\delta=\frac{1}{D^{2}}
$$

Fig. 2 shows the XRD micrographs of electroplated CdTe layers from CdTe-electrolytes at different deposition $\mathrm{pH}$. Based on the observations in Fig. 2, diffraction associable with cadmium tellurate $\left(\mathrm{Cd}_{\mathrm{x}} \mathrm{TeO}_{\mathrm{y}}\right)$ were observed at $2 \theta=$ $\sim 23.0^{\circ}$ across all the explored deposition $\mathrm{pH}$ value. While diffractions at $2 \theta=\sim 20.6^{\circ}, \sim 26.7^{\circ}, \sim 33.8^{\circ}, \sim 37.9^{\circ}, \sim 51.6^{\circ}$, $\sim 60.7^{\circ}$, and $\sim 65.6^{\circ}$ are associable with the underlying glass/FTO layers. The diffractions linkable with the cubic (111), (220) and (311) CdTe phases, which are respectively known to surface at $2 \theta=\sim 24.0^{\circ}, \sim 38.6^{\circ}$, and $\sim 45.8^{\circ}$ [2], [10], [20] were only clearly observed at $2 \theta=\sim 24.0^{\circ}$. therefore, the dominant CdTe phase orientation is clearly identifiable at $2 \theta=\sim 24.0^{\circ}$. The analysis based on the CdTe (111)C diffraction is summarised in TABLE II and Fig. 2.

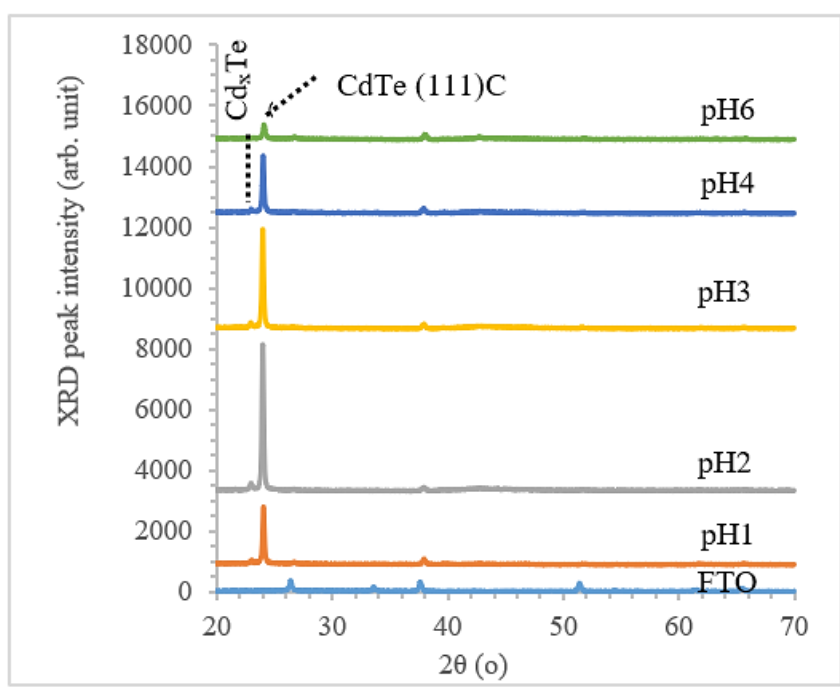

Fig. 2. The XRD spectra of CCT-CdTe thin films deposited at dissimilar bath $\mathrm{pH}$.

TABLE I: ANALYSIS FOR THE CDTE DOMINANT DIFFRACTION AT C(111) FOR CDCL $\mathrm{C}_{2}$ TREATED CDTE LAYERS WITH RESPECT TO DEPOSITION PH

\begin{tabular}{cccccccc}
\hline \hline $\mathrm{pH}$ & $\begin{array}{c}2 \theta \\
\left({ }^{\circ}\right)\end{array}$ & $\begin{array}{c}P_{i}(\mathrm{arb} . \\
\text { unit })\end{array}$ & $\begin{array}{c}\mathrm{d}-\text { space } \\
(\AA)\end{array}$ & $\begin{array}{c}\text { FW HM } \\
\left({ }^{\circ}\right)\end{array}$ & $\begin{array}{c}\mathrm{D} \\
(\mathrm{nm})\end{array}$ & $\varepsilon \times 10^{-3}$ & $\begin{array}{c}\delta \times 10^{11} \\
(\mathrm{lns} \\
\left.\times \mathrm{cm}^{-2}\right)\end{array}$ \\
\hline 1 & 24.0 & 1838.6 & 3.701 & 0.195 & 43.58 & 3.99 & 5.26 \\
2 & 23.9 & 4719.4 & 3.711 & 0.129 & 65.79 & 2.65 & 2.31 \\
3 & 23.9 & 3169.7 & 3.710 & 0.129 & 65.79 & 2.65 & 2.31 \\
4 & 24.0 & 1803.7 & 3.706 & 0.162 & 52.39 & 3.32 & 3.64 \\
6 & 24.1 & 437.3 & 3.692 & 0.195 & 43.54 & 3.98 & 5.28 \\
\hline \hline
\end{tabular}

Furthermore, the observed X-ray diffraction intensity in both Fig. 2 and TABLE I appear to have a direct relationship with the deposition $\mathrm{pH}$. The CdTe layers grown at $\mathrm{pH} 2$ have a comparatively higher diffraction intensity while it is closely followed by the CdTe layers grown at $\mathrm{pH} 3$. A reduction in the intensity was observed outside the $\mathrm{pH} 2$ to $\mathrm{pH} 3$ range. This observation suggests that the highest crystallinity and stoichiometry were achieved for the electroplated $\mathrm{CdTe}$ at $\mathrm{pH} 2$, while $\mathrm{CdTe}$ layers deposited away from this $\mathrm{pH}$ value suffer a reduction in crystallinity. Based on the literature, there is a possibility of etching of the CdTe layer during its growth at the highly acidic pH1.

The etching effect is known to eliminate $\mathrm{Cd}$ from the deposited layer resulting in the Te-richness of the CdTe layer [21], [22]. It should be noted that a clear Te diffraction was not observed in the $\mathrm{pH} 1 \mathrm{CdTe}$ layer due to possible overlap with the FTO diffraction at $2 \theta=\sim 27.5^{\circ}$.

Consequently, deposition at higher $\mathrm{pH}$ value results in the reduction in the acidity of the bath, hence it favours the superfluous deposition of $\mathrm{Cd}$ and the non-availability of $\mathrm{Te}$ due to reduced Te solubility in aqueous solution at high $\mathrm{pH}$. 


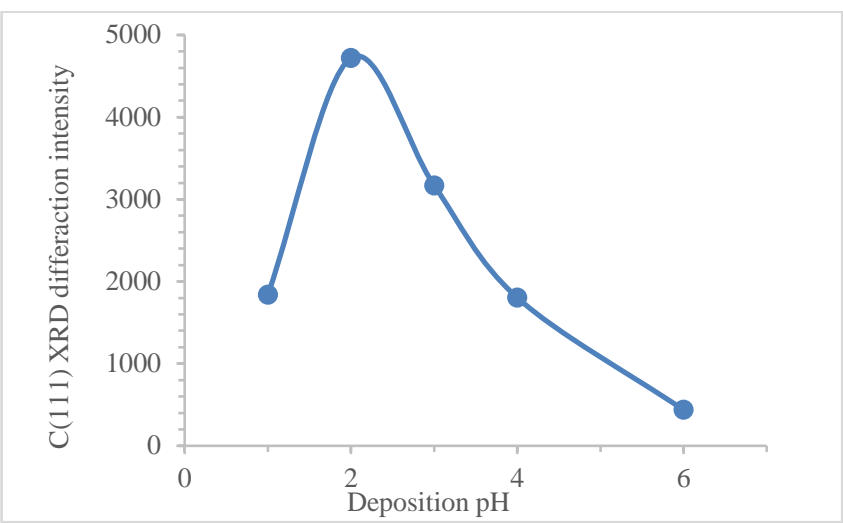

(a)

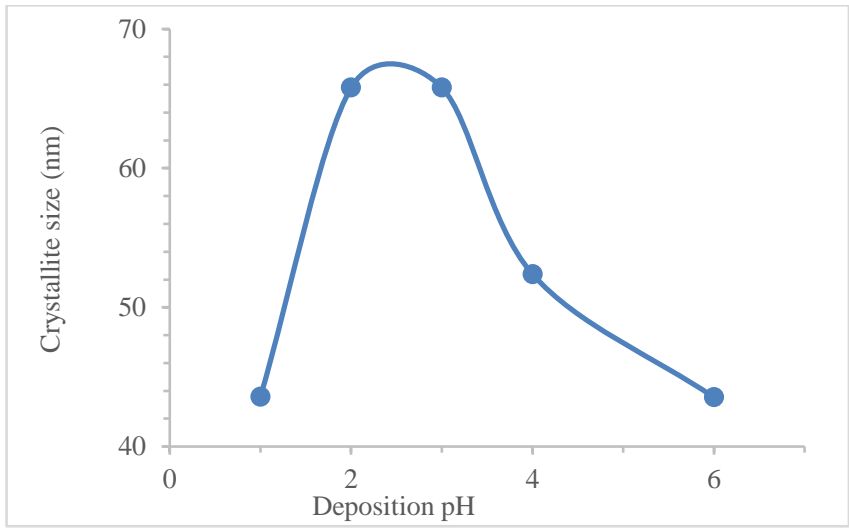

(b)

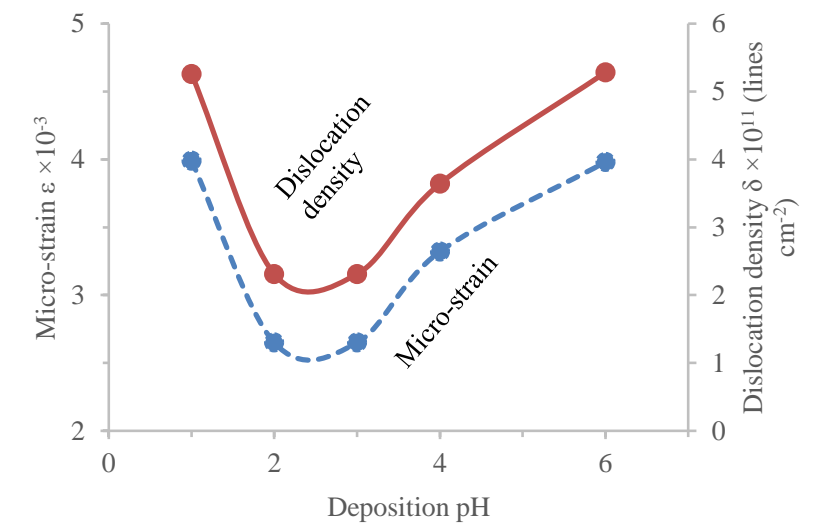

(c)

Fig. 2. Graphical representation of (a) diffraction intensity of CdTe (111)C

(b) estimated crystallite size (c) dislocation density and micro-strain.

A similar trend of estimated crystallite size was also observable in TABLE II and Fig. 2, with the highest crystallites size of $65.79 \mathrm{~nm}$ achieved for the CdTe thinfilms deposited from both $\mathrm{pH} 2$ and $\mathrm{pH} 3$ electrolytes. It is noteworthy that the stagnation of the crystallite size at 65.79 $\mathrm{nm}$ is associable with the deficiencies of either or both the Scherrer's equation and the XRD machine [23], [24].all against deposition $\mathrm{pH}$.

Based on the reduction in the $\mathrm{C}(111)$ CdTe intensity and the calculated crystallite size, the presence of defects such as vacancies, interstitials or dislocations were envisaged. Interestingly, an increase in both the dislocation density and the micro-strain away from the $\mathrm{pH} 2$ and $\mathrm{pH} 3$ range was observed in Table I and Fig. 2.

For the CdTe layers explored, the experimentally observed X-ray diffraction peaks are in concurrence with the cubic CdTe Joint Committee on Powder Diffraction Standards (JCPDS) with file number 01-075-2086. (a) $\mathrm{pHI}-\mathrm{AD}$

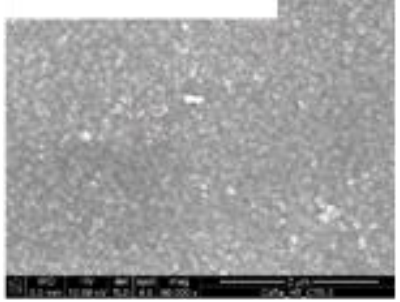

(b) $\mathrm{pH} 2-\mathrm{AD}$
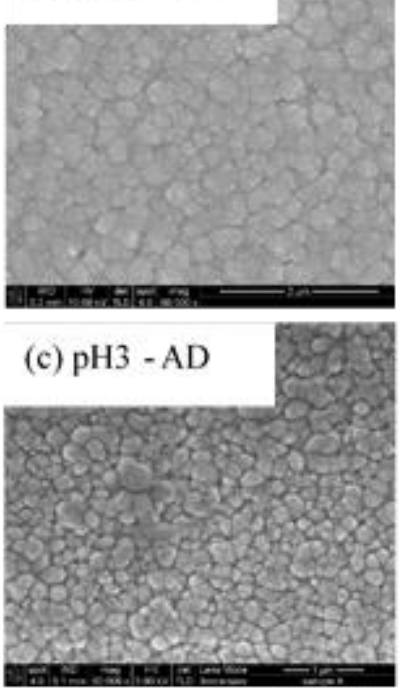

(g) $\mathrm{pH} 3$ - CCT

(d) $\mathrm{pH} 6$ - AD

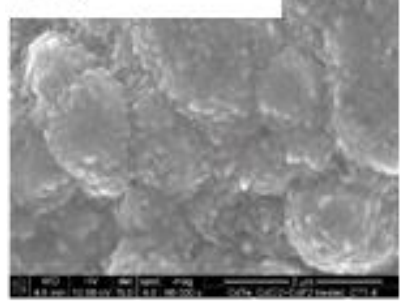

(e) $\mathrm{pHI}$ - CCT
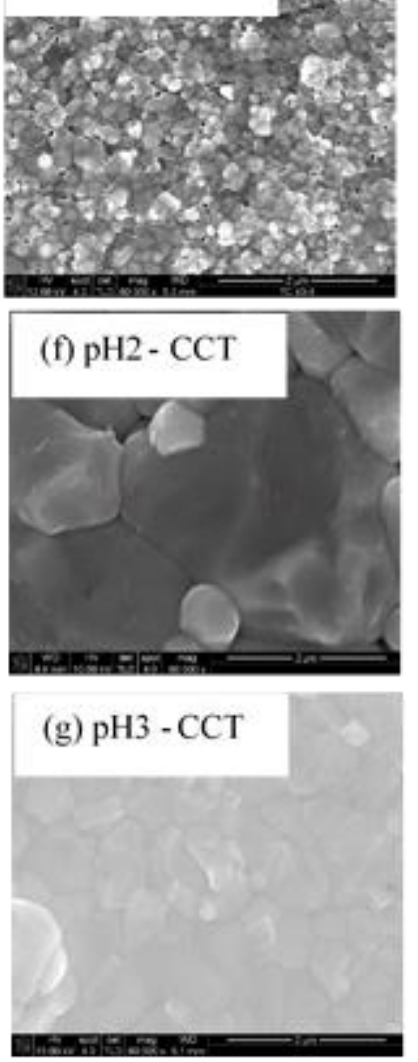

(h) $\mathrm{pH} 6$ - CCT

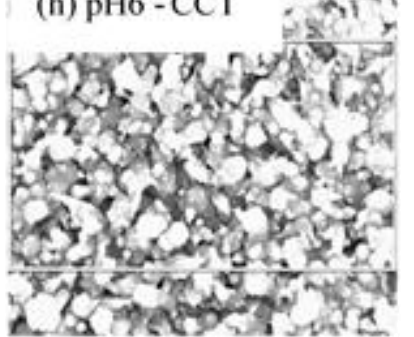

Fig. 3. SEM images of AD-CdTe layers grown at (a) pH1, (b) pH2, (c) $\mathrm{pH} 3$, and (d) $\mathrm{pH} 6$ and the corresponding $\mathrm{CCT}$ at (e) $\mathrm{pH} 1$, (f) $\mathrm{pH} 2,(\mathrm{~g}) \mathrm{pH} 3$ and (h) $\mathrm{pH} 6$.

\section{Morphological and Compositional Study}

The FEI Nova200 NanoSEM integrated with energy dispersive X-ray (EDX) detector system was utilised in performing both the morphological and compositional study for the CdTe samples. The experiments were conducted under vacuum conditions. For all the explored CdTe thin films, the magnification was set to $\times 60000$.

The SEM micrographs of both the AD and CCT-CdTe layers grown at different deposition layers are shown in Fig. 4. The AD-CdTe layers grown at (a) $\mathrm{pH} 1$, (b) $\mathrm{pH} 2$, (c) $\mathrm{pH} 3$, and (d) pH6 and the corresponding CCT at (e) pH1, (f) pH2, (g) pH3 and (h) pH6 is as shown in Fig. 4. As observed, all the electroplated layers across the investigated deposition $\mathrm{pH}$ show good underlying substrate coverage under the $\mathrm{AD}$ condition. It was also observed that the formation of grains looks somewhat different with curly floral grain formation [2] observed for the AD- CdTe layers deposited at $\mathrm{pH} 2$ and pH3 (See Fig. 4 (b-c)). After CCT, deterioration in the electroplated CdTe layers was observed for both the $\mathrm{pH} 1$ and pH6 layers in Fig. 4 (e) and Fig. 4 (h), respectively. The gaps and/or pinholes observed in Fig. 4 (e) and Fig. 4 (h) 
could act as shunting paths provided the layers are incorporated in PV configuration. For such PV systems, poor fill factor, low open-circuit voltage, and resultant low conversion efficiency will be observed. The CCT CdTe layers grown at $\mathrm{pH} 2$ and $\mathrm{pH} 3$ show distinctive grain growth with no observable pinhole and limited grain boundaries (See Fig. 4 (f) and Fig. 4 (g)).

In relation to the summations made in Section 3.2, it is better understood that the observed grain growth in the $\mathrm{pH} 2$ and $\mathrm{pH} 3$ grown CdTe layers is an indication of a reduction in the lattice defects, resulting in a reduction in both the internal strain $\varepsilon$ and dislocation density $\delta$ [25]. Another improvement in the characteristic properties of CdTe layers after CCT has been captured in numerous literature [26], [27].

Fig. 4 and TABLE II summarises the EDX spectra data of electrodeposited CdTe layers after CCT. For all the explored deposition $\mathrm{pH}$, the presence of elemental $\mathrm{Cd}$ and $\mathrm{Te}$ was observed.

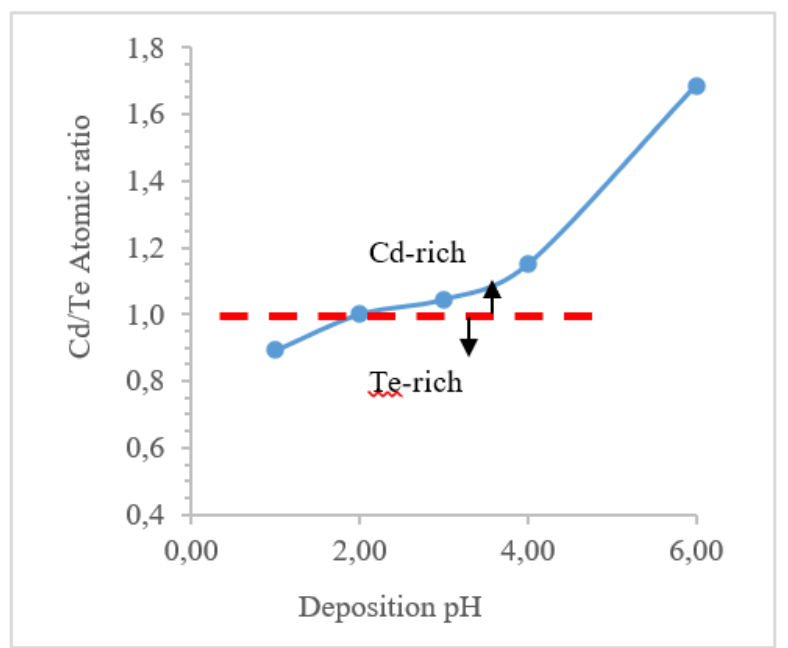

Fig. 4. Graph of $\mathrm{Cd} / \mathrm{Te}$ atomic compositions ratio against deposition $\mathrm{pH}$.

It is notable that the presence of fluorine $(\mathrm{F})$, tin $(\mathrm{Sn})$, oxygen $(\mathrm{O})$ can be observed due to its presence as the main element in the underlying FTO. As observed in TABLE II, a gradual decrease in the Te concentration was observable with increasing $\mathrm{pH}$ and a reverse trend can be said of elemental $\mathrm{Cd}$. This might be as a result of the increased solubility of $\mathrm{Te}$ at low $\mathrm{pH}$ (high acidity) [28], [29]. The solubility of Te has also been documented in the literature to be affected by other deposition parameters such as deposition temperature [30] amongst others. The presence of the underlying elemental Sn was observed for the CdTe layers deposited at both (the highly acidic) $\mathrm{pH} 1$ and (the bear neutral) pH6. This observation can be attributed to the deterioration of the thin-films after post-growth treatment as shown in Fig. 3 (e) and Fig. 3 (h). The deposited CdTe layers at $\mathrm{pH} 2$ show a $1: 1$ atomic ratio of $\mathrm{Cd}$ to $\mathrm{Te}$ which suggests stoichiometry and comparatively suitable for PV applications. It should be taken into consideration that the shift towards 1:1 atomic composition ratio of $\mathrm{Cd}$ : Te for CCT CdTe layers can be a resultant of the reaction between $\mathrm{Cd}$ from $\mathrm{CdCl}_{2}$ and unreacted elemental Te, and/ or the sublimation of superfluous elemental $\mathrm{Cd}$ and $\mathrm{Te}$ in the layers [2], [26].
TABLE II: SUMMARY OF THE EDX SPECTRA OF ELECTRODEPOSITED CDTE

\begin{tabular}{ccccc}
\multicolumn{5}{c}{ THIN-FILMS AFTER CCT } \\
\hline \hline $\mathrm{pH}$ & $\mathrm{Cd}$ & $\mathrm{Te}$ & $\mathrm{Sn}$ & $\mathrm{Cd} / \mathrm{Te}$ \\
\hline 1 & 37.9 & 42.9 & 19.6 & 0.89 \\
2 & 50.0 & 50.0 & 0.0 & 1.00 \\
3 & 51.1 & 48.9 & 0.0 & 1.04 \\
4 & 53.5 & 46.5 & 0.0 & 1.15 \\
6 & 44.7 & 26.5 & 28.9 & 1.69 \\
\hline \hline
\end{tabular}

\section{Photoelectrochemical (PEC) Study}

The determination of the electrical conduction type of the semiconductor under consideration is achieved using PEC cell measurements. This is done by making a solid/liquid junction between the glass/FTO/CdTe and the conductive electrolyte. For consistency in the works put forward by the principal author's group, $0.1 \mathrm{M}$ sodium thiosulphate $\left(\mathrm{Na}_{2} \mathrm{~S}_{2} \mathrm{O}_{3}\right)$ is dissolved in $20 \mathrm{ml}$ of DI water used as the PEC-electrolyte. When illuminated, electrons are energised and promoted to the conduction band for photo-active semiconductor materials, hence, electric current is generated. The PEC signal is the measured voltage difference between the readings taken under both illuminated $\left(\mathrm{V}_{\mathrm{L}}\right)$ and dark conditions $\left(\mathrm{V}_{\mathrm{D}}\right)$. Before measurements were taken, a known n-type material (n-CdS) was utilised to calibrate the PEC system. The mathematical signal signifies the electrical conduction type and the magnitude signifies the suitability of doping concentration of the semiconducting layer for fabricating electronic devices [31].

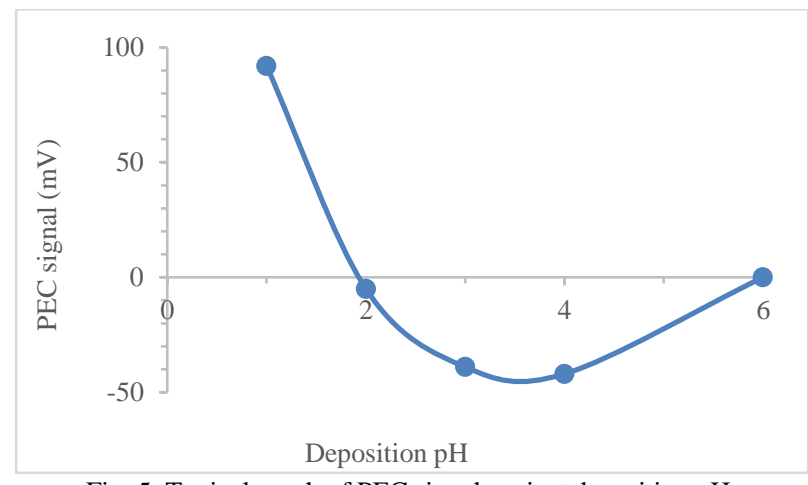

Fig. 5. Typical graph of PEC signal against deposition $\mathrm{pH}$.

Prior to the measurements of the layers under investigation, a known n-type CdS layer was utilised for the calibration of the system.

The obtained PEC signal is summarised in Fig. 5. It signifies that the deposited CdTe layers at $\mathrm{pH} 1$ are p-type, the CdTe layers deposited at higher deposition $\mathrm{pH}$ are n-type except for the pH6 CdTe layer with a $0 \mathrm{mV}$ PEC signal. A linkage between the Te-richness and Cd-richness in CdTe has been known to be one of the factors determining the respective $\mathrm{p}$-type or $\mathrm{n}$-type electrical conduction of the layers [2], [10]. It is also noteworthy that PEC signals can be $0 \mathrm{mV}$ or close provided the photovoltaic material under investigation is a metal -with overlapping bands, an insulator -with a large bandgap or intrinsic semiconductor with the Fermi level at the mid-gap. It is a possibility that due to the CdTe layer quality with the incorporation of the pores and gaps, possible contact between the PEC electrolyte and the underlying conductor (glass/FTO) is envisaged which will evidently give a PEC signal of $0 \mathrm{mV}$. 


\section{CONCLUSION}

The electrodeposition and characterisation of twoelectrode electroplated $\mathrm{CdTe}$ with respect to the deposition $\mathrm{pH}$ value within the acidic range was carried out successfully and systematically documented. The bandgap energy of the CCT-CdTe layers grown across the explored $\mathrm{pH}$ is within the tolerable range of $1.44 \pm 0.03 \mathrm{eV}$. The XRD studies showed that the CdTe layers grown are crystalline under both as deposited and CCT conditions. Morphologically, the AD-CdTe layers show full underlying substrate coverage, while deterioration in the $\mathrm{pH} 1$ and $\mathrm{pH} 6$ were observed after CCT. Grain growth, reduced grains boundary amongst other improvements were observed for the $\mathrm{pH} 2, \mathrm{pH} 3$ and $\mathrm{pH} 4$ grown CdTe layers. The PEC cell measurements showed that p-type was observed for the $\mathrm{pH} 1$ layer, and the layers grown at $\mathrm{pH} 2, \mathrm{pH} 3$ and $\mathrm{pH} 4$ are n-type in nature. Based on all the gathered

\section{ACKNOWLEDGMENT}

The main author would like to thank the Materials and Engineering Research Institute (MERI), Sheffield Hallam Univer- sity (SHU), UK, for the facilities made available for the work reported in this paper. The authors would like to acknowledge Prof. Dharmadasa and other members of the SHU Solar Energy Group for their contri- butions. The main author wishes to also thank Ekiti State University (EKSU), Ado Ekiti, Nigeria, for their support.

\section{REFERENCES}

[1] T. L. Chu and S. S. Chu, "Recent progress in thin-film cadmium telluride solar cells," Prog. Photovoltaics Res. Appl., vol. 1, no. 1, pp. 31-42, 1993

[2] A. A. Ojo, W. M. Cranton, and I. M. Dharmadasa, Next Generation Multilayer Graded Bandgap Solar Cells. Cham: Springer International Publishing, 2019.

[3] O. I. Olusola, M. L. Madugu, and I. M. Dharmadasa, "Investigating the electronic properties of multi-junction $\mathrm{ZnS} / \mathrm{CdS} / \mathrm{CdTe}$ graded bandgap solar cells," Mater. Chem. Phys., vol. 191, pp. 145-150, 2016.

[4] O. K. Echendu, F. Fauzi, A. R. Weerasinghe, and I. M. Dharmadasa, "High short-circuit current density CdTe solar cells using allelectrodeposited semiconductors," Thin Solid Films, vol. 556, pp 529-534, Apr. 2014.

[5] A. A. Ojo, H. I. Salim, and I. M. Dharmadasa, "The influence of $\mathrm{ZnS}$ crystallinity on all-electroplated $\mathrm{ZnS} / \mathrm{CdS} / \mathrm{CdTe}$ graded bandgap device properties," J. Mater. Sci. Mater. Electron., vol. 29, no. 16, pp. 13631-13642, Aug. 2018.

[6] P. U. Londhe and N. B. Chaure, "Effect of $\mathrm{pH}$ on electrodeposited $\mathrm{ZnO}$ thin films," AIP Conf. Proc., vol. 1447, no. 1, pp. 671-672, 2012.

[7] F. S. B. Kafi, K. M. D. C. Jayathileka, R. P. Wijesundera, and W. Siripala, "Effect of Bath $\mathrm{pH}$ on Interfacial Properties of Electrodeposited n-Cu 2 O Films," Phys. status solidi, vol. 1700541 , p. 1700541, Jan. 2018.

[8] M. Rami, E. Benamar, M. Fahoume, and A. Ennaoui, "Growth analysis of electrodeposited CdS on ITO coated glass using atomic force microscopy," Phys. Status Solidi a-Applied Res., vol. 172, no. 1, pp. 137-147, 1999

[9] A. A. Ojo and I. M. Dharmadasa, "Analysis of electrodeposited CdTe thin films grown using cadmium chloride precursor for applications in solar cells," J. Mater. Sci. Mater. Electron., vol. 28, no. 19, pp. 14110-14120, Oct. 2017.

[10] H. I. Salim, V. Patel, a. Abbas, J. M. Walls, and I. M. Dharmadasa, "Electrodeposition of CdTe thin films using nitrate precursor for applications in solar cells," J. Mater. Sci. Mater. Electron., vol. 26, no. 5, pp. 3119-3128, 2015.
[11] I. Dharmadasa et al., "Electroplating of CdTe Thin Films from Cadmium Sulphate Precursor and Comparison of Layers Grown by 3 Electrode and 2-Electrode Systems," Coatings, vol. 7, no. 2, p. 17, Jan. 2017.

[12] O. I. O. Olusola, M. L. Madugu, and I. M. Dharmadasa, "Growth of n-and p-type ZnTe semiconductors by intrinsic doping," Mater. Res. Innov., vol. 19, no. 7, pp. 497-502, 2015.

[13] J. Tauc and A. Menth, "States in the gap," J. Non. Cryst. Solids, vol. 8-10, pp. 569-585, 1972.

[14] A. Bosio, N. Romeo, S. Mazzamuto, and V. Canevari, "Polycrystalline CdTe thin films for photovoltaic applications," Prog. Cryst. Growth Charact. Mater., vol. 52, no. 4, pp. 247-279, Dec. 2006.

[15] T. L. Chu and S. S. Chu, "Thin film II-VI photovoltaics," Solid. State. Electron., vol. 38, no. 3, pp. 533-549, Mar. 1995

[16] I. M. Dharmadasa et al., "Improvement of composition of CdTe thin films during heat treatment in the presence of $\mathrm{CdCl} 2, "$ J. Mater. Sci. Mater. Electron., vol. 28, no. 3, pp. 2343-2352, Feb. 2017.

[17] I. M. Dharmadasa et al., "Effects of $\mathrm{CdCl} 2$ treatment on deep levels in CdTe and their implications on thin film solar cells: a comprehensive photoluminescence study," J. Mater. Sci. Mater. Electron., vol. 26, no. 7, pp. 4571-4583, 2015.

[18] G. K. Williamson and W. H. Hall, "X-ray line broadening from filed aluminium and wolfram," Acta Metall., vol. 1, no. 1, pp. 22-31, Jan. 1953.

[19] G. K. Williamson and R. E. Smallman, "Dislocation densities in some annealed and cold-worked metals from measurements on the X-ray debye-scherrer spectrum," Philos. Mag., vol. 1, no. 1, pp. 34-46, Jan. 1956.

[20] N. A. Abdul-Manaf, H. I. Salim, M. L. Madugu, O. I. Olusola, and I M. Dharmadasa, "Electro-Plating and Characterisation of CdTe Thin Films Using CdCl2 as the Cadmium Source," Energies, vol. 8, no. 10, pp. 10883-10903, 2015.

[21] I. M. Dharmadasa, "Recent developments and progress on electrical contacts to CdTe, CdS and $\mathrm{ZnSe}$ with special reference to barrier contacts to CdTe," Prog. Cryst. Growth Charact. Mater., vol. 36, no. 4, pp. 249-290, Jan. 1998.

[22] A. A. Ojo and I. M. Dharmadasa, "Optimisation of $\mathrm{pH}$ of cadmium chloride post-growth-treatment in processing CdS/CdTe based thin film solar cells," J. Mater. Sci. Mater. Electron., vol. 28, no. 10, pp 7231-7242, May 2017

[23] A. Monshi, "Modified Scherrer Equation to Estimate More Accurately Nano-Crystallite Size Using XRD," World J. Nano Sci. Eng., vol. 02, no. 03, pp. 154-160, 2012.

[24] A. Bouraiou, M. S. Aida, O. Meglali, and N. Attaf, "Potential effect on the properties of $\mathrm{CuInSe} 2$ thin films deposited using two-electrode system," Curr. Appl. Phys., vol. 11, no. 5, pp. 1173-1178, 2011.

[25] R. Barir, B. Benhaoua, S. Benhamida, A. Rahal, T. Sahraoui, and R. Gheriani, "Effect of Precursor Concentration on Structural Optical and Electrical Properties of NiO Thin Films Prepared by Spray Pyrolysis," J. Nanomater., vol. 2017, pp. 1-10, 2017.

[26] I. M. Dharmadasa, "Review of the $\mathrm{CdCl} 2$ Treatment Used in CdS/CdTe Thin Film Solar Cell Development and New Evidence towards Improved Understanding," Coatings, vol. 4, no. 2, pp. 282 $307,2014$.

[27] H. R. Moutinho et al., "Studies of recrystallization of CdTe thin films after CdC12 treatment," Conf. Rec. Twenty Sixth IEEE Photovolt. Spec. Conf. - 1997, no. September, 1997.

[28] T. Mahalingam, V. S. John, S. Rajendran, and P. J. Sebastian, "Electrochemical deposition of ZnTe thin films," Semicond. Sci. Technol., vol. 17, no. 5, pp. 465-470, 2002.

[29] X. Li et al., "Electrodeposition of mesoporous CdTe films with the aid of citric acid from lyotropic liquid crystalline phases," J. Mater. Chem., vol. 16, no. 31, p. 3207,2006

[30] M. Soliman, a. B. Kashyout, M. Shabana, and M. Elgamal, "Preparation and characterization of thin films of electrodeposited CdTe semiconductors," Renew. Energy, vol. 23, no. 3-4, pp. 471481, 2001.

[31] N. B. Chaure, A. P. Samantilleke, R. P. Burton, J. Young, and I. M. Dharmadasa, "Electrodeposition of $\mathrm{p}(+), \mathrm{p}, \mathrm{i}, \mathrm{n}$ and $\mathrm{n}(+)$-type copper indium gallium diselenide for development of multilayer thin film solar cells," Thin Solid Films, vol. 472, no. 1-2, pp. 212-216, 2005. 


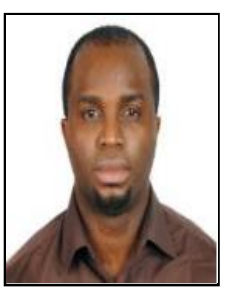

Ayotunde A. Ojo hails from Ekiti State, Nigeria. $\mathrm{He}$ obtained Bachelor of Engineering in Mechanical Engineering, University of Ado-Ekiti, Ado-Ekiti, Nigeria, (2005), Masters of Science in Advanced Engineering and Management, Sheffield Hallam University, Sheffield, United Kingdom, (2010), and $\mathrm{PhD}$ in Mechanical Engineering, Sheffield Hallam University, Sheffield, United Kingdom, (2017). He is a lecturer in the Department of Mechanical Engineering, Faculty of Engineering, Ekiti State University, Ado-Ekiti. His areas of specialization are renewable energy (photovoltaics), material, and thermofluids. Dr. Ojo is a corporate member of Nigeria Society of Engineers.

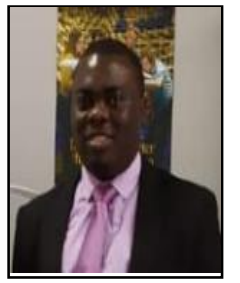

Kolade A. Olanipekun is a graduate of Mechanical Engineering from the University of Ado Ekiti (now Ekiti State University), where he was awarded a B.Eng. Mechanical Engineering in year 2006. He proceeded to the University of Liverpool, UK in year 2009 and bagged a M.Sc. (Eng.) degree in Aerospace and Mechanical Systems Engineering in year 2010. He got his $\mathrm{PhD}$ in Engineering and Environment from Institute of Sound and Vibration Research (ISVR), University of Southampton, UK in year 2020.

He started lecturing as an Adjunct lecturer in the University of Ado Ekiti (now Ekiti State University) in year 2011 because of his interest in academics and research. He later started as a full time lecturer in year 2012 in the same university. He is currently lecturing in the Department of Mechanical Engineering, Ekiti State University, Ado Ekiti where he teaches modules like Machine Design, Engineering Mechanics (Statics and Dynamics) and Mechanical Vibration. He has published the following articles among others:

1. Ojo A.A., Olanipekun K. A., Akomolede A.M., (2018) "A Comparative Study on the use of Natural and Synthetic Materials as Noise Reducing Media in the Silencers of Internal Combustion Engine", International Journal of Engineering Technology and Management (IJETM), 5)3: 22-28.

2. Awogbemi O., Adebayo A., Olanipekun K. A., February, (2016), "Investigation into the use of some locally available Vegetable Oil as Damping Fluid", Journal of Multidisciplinary Engineering Science and Technology (JMEST), (3)2: 4021-4029.

3. K. A. Olanipekun, E. Rustighi and N.S. Ferguson (2019), "Active vibration control of planetary gears by pole placement", Journal of Physics: Conference Series 1264 (2019) 012004, doi: 10.1088/17426596/1264/1/012004.

Dr Olanipekun is a Corporate Member of Nigerian Society of Engineers (NSE) and a Registered Mechanical Engineer in Nigeria.

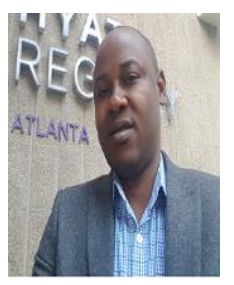

Benjamin S. Oluwadare was born on 16th October 1978 in Ilupeju Ekiti, Ekiti State, Nigeria. He completed his undergraduate programme at the University of Ado Ekiti, Nigeria, in December 2005 with Second Class Upper Division in Mechanical Engineering. Benjamin obtained a master's degree in Industrial/Production Engineering from Nnamdi Azikiwe University, Awka, in January 2010. He studied for a PhD in Mechanical Engineering at the University of Sheffield, United Kingdom and completed his PhD programme in March 2020. Benjamin's major field of study is thermofluids.

$\mathrm{He}$ is currently a SENIOR LECTURER in the Department of Mechanical Engineering, Ekiti State University, Ado Ekiti, Nigeria. He worked as a GRADUATE TEACHING ASSISTANT in the Department of Mechanical Engineering, the University of Sheffield, between 2015 and 2019. His published articles include: Oluwadare, B. S., Mathur, A., and He, S. (2017). Study of Turbulence in Unsteady Flows using Particle Image Velocimetry (PIV) and Constant Temperature Anemometry (CTA). Bulletin of the American Physical Society (APS), Vol., 62, No., 24. (USA); Oluwadare B. S., and He, S. (2018). Effect of Varying Reynolds Number Ratio on Transition to Turbulence in Unsteady Flows. In Proc. of the 48th AIAA Fluid Dynamics Conference, pp 1-16. (USA). Oluwadare B. S., and He, S. (2018); Study Response of Turbulence in Transition of Unsteady Channel Flows. In Proc. of the 5th International Conference of Fluid Flow, Heat and Mass Transfer, Paper No 132, pp 1 8. (Canada). His current research focuses on unsteady turbulent flow using Reynolds Averaged Navier-Stokes Equation (RANS Equation)

Dr Oluwadare is a registered member of the Council for the
Regulation of Engineering in Nigeria (COREN) and member of International Association of Engineers (IAENG)

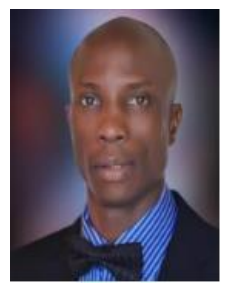

Taiwo O. Oni obtained a B.Eng degree, an M.Eng degree, and a Ph.D degree in Mechanical Engineering from Ondo State University, AdoEkiti (now known as Ekiti State University, AdoEkiti), Nigeria, Federal University of Technology, Akure, Nigeria, and University of Glasgow, Glasgow, United Kingdom, respectively. His research areas are heat and mass transfer, fluid mechanics, thermodynamics, energy, refrigeration,

and air-conditioning.

$\mathrm{He}$ is an Associate Professor of Meechanical Engineering in the Department of Mechanical Engineering at Ekiti State University, AdoEkiti, Nigeria, and a member of Thermofluids Division within the Department. He is an author and a co- author of several peer-reviewed articles published in reputable international journals and conference proceedings. He is also a co- author of a textbook on fluid mechanics. Moreover, he is a reviewer of some reputable international journals.

Dr. Oni is a member of International Association of Engineers (IAENG) Hong Kong in China, Council for the Regulation of Engineering in Nigeria (COREN), and Nigerian Society of Engineers (NSE). His other professional memberships are Nigerian Institution of Mechanical Engineers (NIMechE), and Chartered Management Institute (CMI), UK. 